\title{
ДОСВІД СТВОРЕННЯ ЛІКАРНІ ВРОЦЛАВСЬКОЇ МЕДИЧНОЇ АКАДЕМІЇ $З$ ОГЛЯДУ НА ПРОБЛЕМИ РЕФОРМУВАННЯ МЕДИЧНОЇ ГАЛУЗІ В УКРАЇНІ
}

О. В. Олійник

\begin{abstract}
ДВНЗ “Тернопільський держсавний медичний університет імені І. Я. Горбачевського МОЗ Украӥни”
EXPERIENCE OF THE CREATION OF THE CLINIC OF MEDICAL ACADEMY OF WROCLAW TAKING INTO CONSIDERATION THE PROBLEMS OF REFORMING OF MEDICAL BRANCH IN UKRAINE
\end{abstract}

\author{
O. V. Oliynyk \\ SHEI “Ternopil State Medical University by I. Ya. Horbachevsky of MPH of Ukraine”
}

\begin{abstract}
Стаття присвячена вивченню досвіду клініки медичної академії Вроцлава та можливості використання цього досвіду при реформуванні вітчизняної медичної галузі.
\end{abstract}

This article is devoted to studying the experience of the clinic of Medical Academy of Wroclaw and the possibility of using this experience in the process of reforming of the national healthcare system.

Вступ. Наша держава вийшла зараз на нелегкий шлях реформування медицини. МО3 України запропонував зміни, які передбачають укрупнення лікарень, створення центрів невідкладної допомоги, які були б незалежними від інших лікарських закладів та обладнані сучасним устаткуванням [1]. В чотирьох областях України ці пілотні проекти вже є чинними [2]. В Інтернеті розміщені проекти реформування медицини, які передбачають частковий перехід на засади страхової медицини. Проте процеси реформ зустрічають певний опір, зумовлений багатьма причинами. Наші сусіди, зокрема поляки, вже пройшли через це. Не можна сказати, що процес реформ в Польщі був безболісним, але він майже скінчився, i, на думку автора статті, є досить вдалим. Результати реформування польської медичної галузі можна розглянути на прикладі лікарні Вроцлавської медичної академії.

Основна частина. Реформування медицини почалось у Польщі в 1999 році, коли всі клінічні лікарні були передані від різних об'єктів господарювання Міністерству охорони здоров’ я Польщі. У 2001 році Міністерство охорони здоров'я передало клінічні лікарні в підпорядкування медичних університетів. Вроцлавська академічна лікарня була створена у 2002 році на базі Вроцлавської дитячої лікарні та міських лікарень № 3 та № 5. В 2002-2006 роках Академічна лікарня функціонувала на 13 різних базах, які нараховували 31 клініку. У 2003 році почалась робота 3 організації лікарні, яка б знаходилась в одному місці.
Цей процес закінчився у 2009 році. Було створено лікарню, яка "сппеціалізується на наданні медичних послуг підвищеної якості та використовує підвищені стандарти лікування". На даний момент в лікарні функціонує 17 клінік та 38 спеціалізованих відділень. За Свропейськими стандартами працюють відділення анестезіології та інтенсивної терапії, судинної хірургії, кардіохірургії, трансплантології, матері і дитини. На базі лікарні працює відділення невідкладної допомоги, аналог наших центрів екстреної медичної допомоги. Відділення обладнане площадкою для посадки гелікоптерів, якими при потребі здійснюється транспортування пацієнтів. Лікарня є найбільшою базою для післядипломного підвищення кваліфікації лікарів Нижньої Сілезії. В найближчих планах - створення центру лікування уражень голови і шиї.

Однією із найпотужніших клінік $є$ клініка анестезіології та інтенсивної терапії. На ії чолі стоїть доктор медичних наук, професор Анджей Кіблер. У відділенні анестезіології розгорнуто 25 ліжок. Загальна площа відділення, за підрахунками автора статті, близько 4000 м². Річний бюджет відділення складає близько 5 млн євро. В клініці дотримуються стандартів Свропейського Союзу щодо лікування та обстежень пацієнтів. Денне перебування пацієнта в клініці коштує в середньому 1500 євро. Медицина в Польщі залишається державною. Пацієнт не платить ні за ліки, ні за медичні послуги. За європейськими стандартами, на одного пацієнта у відділенні має бути близько 
10 шприцевих насосів, що виконується в лікарні. Стандартом є встановлення артеріального катетера, 3 якого береться кров для виконання лабораторних досліджень і за допомогою якого проводиться інвазійне вимірювання артеріального тиску. Кожних чотири години виконується дослідження газів крові, кислото-лужного та водно-електролітного балансів. Постійно моніторується центральний венозний тиск. Як центральний венозний доступ найчастіше використовується внутрішня югулярна вена.

Відділення оснащене 8 апаратами для гемофільтрації та 4 - для гемодіалізу. Гемофільтрація використовується в терапії важкого сепсису. Останній виявляється приблизно у 25-30 \% хворих, які перебувають у BAIT. Завдяки застосуванню цього методу значно знизилась смертність при панкреонекрозах. Показник смертності від важкого сепсису у відділенні становить приблизно 50 \%. Перевагою гемофільтрації порівняно з гемодіалізом є невеликий вплив на гемодинаміку та можливість проведення методики без використання гепаринів. Більшості хворих на важкий сепсис гемофільтрацію призначають майже відразу 3 початком лікування, що значно покращує результати терапії. Вартість одного апарата для гемофільтрації становить близько 23 тис. євро. Завідувач клініки проф. Кіблер приділяє велику увагу своєчасній діагностиці та лікуванню сепсису. Він є головним редактором знаного в Свропі медичного журналу “Сепсис".

В лікарні працює потужне операційне відділення. Площа операційних' за підрахунками автора, становить близько 10000 м². Функціонує 34 операційних театри, оснащених апаратами для наркозу DatexOmeda, моніторами, які, крім показників гемодинаміки, газів, оснащені BIS-моніторами та моніторами для визначення рівня релаксації периферичної мускулатури. В якості анестетиків найчастіше використовуються севофлюран та пропофол. Дуже широко розповсюджена спинальна анестезія. В операційному блоці є пересувні комп'ютерний томограф та апарат МРТ, сучасний мікроскоп для нейрохірургії, обладнання для операцій на серці та багато іншої апаратури. Широко розповсюджена малолінвазивна хірургія, зокрема в урології велику частину нефректомій та видалень передміхурової залози, виконаних з приводу пухлинних захворювань, виконують малоінвазивно.

\section{Лiтература}

1. Стратегія реформування системи охорони здоров'я України. - http://www.uiph.kiev.ua/uploads/docs/ presentation/stategiya_reformuvannya.pdf
В операційному відділенні функціонує палата для післяопераційного догляду на 24 ліжка (12 для “чистих” і 12 для “гнійних" хворих). Палата обладнана необхідним устаткуванням від респіраторів, моніторів, апаратури для реанімації до бронхоскопів. Всі ліжка для транспортування хворих укомплектовані портативними моніторами та портативними вентиляторами. Хоча, по суті справи, кожне ліжко - це пересувний операційний стіл. Перекладання хворого з ліжка виконує автоматизований пристрій.

Всі приміщення як в операційному блоці, так і у BAIT обладнані примусовою вентиляцією 3 від’ємним тиском. Двері закриваються герметично, що значно знижує ризик розповсюдження інфекцій. Дуже великі вимоги щодо антисептики. Біля ліжок пацієнтів та біля вихідних дверей на стінах висять пристрої з дезінфікуючою рідиною. Після проведення маніпуляцій, після огляду чи контакту з пацієнтом персонал обов'язково обробляє руки антисептиком.

Документація щодо історій хвороби пацієнта, включаючи численні аналізи, вноситься в комп'ютерну мережу. Працівники відділення мають свої логіни та паролі для входу в систему і можливості ознайомлення $з$ обстеженнями.

Значна частина лікарів клініки одночасно є викладачами академії. Анестезіологію у Вроцлавській медичній академії викладають на 5 курсі протягом 2-х тижнів. В перший студенти щодня мають 4-годинне теоретичне заняття та семінар. На другому тижні теоретичні питання заміняють практичними біля ліжка хворого. Навантаження викладача анестезіології в університеті становить 210 годин на рік.

У Вроцлавській медичній академії видається журнал-Advances in clinical and experimental medicine. $\mathrm{Y}$ цьому виданні приймають до друку статті польською та англійською мовами. Журнал є знаним в Свропі, має достатній імпакт-фактор. Крім того, науковці можуть читати Інтернет-видання журналу Pediatric Endocrinology, Diabetes and Metabolism та надсилати туди свої статті. Електронна адреса журналу http:// cornetis.pl/pl/czasopisma/szczegoly/id/2

Висновки: 1. Польща добилась значних позитивних змін в реформуванні системи охорони здоров'я, які були розпочаті ще в 1999 році.

2. Досвід Польщі в реформуванні системи охорони здоров' я було б корисно використати в Україні.

2. Інтегральна складова реформування системи охорони здоров'я в Україні // Вісник Міністерства охорони здоров’я № 46. Ваше здоров’я. -2011.-№ 8 . 